\title{
Voluntary Assurance of Sustainability Report and Audit Fees
}

\author{
Qi Zhao ${ }^{1}$ \\ ${ }^{1}$ Guangdong University of Foreign Studies, Guangzhou, China \\ Correspondence: Qi Zhao, postgraduate student, Guangdong University of Foreign Studies, Guangzhou, China.
}

Received: August 5, 2017

Accepted: August 17, 2017

Online Published: August 21, 2017

doi:10.5430/jms.v8n4p47

URL: https://doi.org/10.5430/jms.v8n4p47

\begin{abstract}
The 21 th century has seen huge changes of corporations. While companies' business grew rapidly, attention and recognition on corporate social responsibility has gradually been attracted and put on a vital strategy position. It has been proofed to be a crucial way that enterprises share their social responsibility actively in order to enhance their competitive advantage. With more and more enterprises knowing how important social responsibility is for their development, they released a new method which is called sustainability report to show them determine and confidence to take social responsibility.

This thesis can be divided into six parts. The first part is about introduction and background. The second part is literature review. The third part is the development of hypotheses. The fourth part is research method and the fifth part is a conclusion. The last part is the reference.
\end{abstract}

Keywords: corporation, social responsibility, sustainability report

\section{Introduction and Background}

Sustainability report, also known as corporate social responsibility report, derives from corporate environmental report. It is a non financial report. Through years of reforms, sustainability report has become general non profit report which spread sustainability ideas and public information to those stakeholders. Now, more than mere environmental information in the past, the report shows relevant corporate information in economic, social fields, etc.

Although it is a positive side to see more and more enterprises release their sustainability reports and strengthen their sense of taking social responsibility, the quality of reports varies from one company to another due to lack of relevant policy and standard. Under such circumstance, the third party's assurance occurs, they aim to enhance the enterprise social responsibility report confidence level. This service provided by the third party gives reliable reference to stakeholders and report users. It is without doubt that its independent and professional power can truly judge good from bad and better an enterprise's quality of practice behavior.

This is, however, another extra cost for a company, so those who carry out voluntary assurance of sustainability report would be thought as a powerful behavior to fulfill their social responsibility. Besides, voluntary assurance of sustainability report can also raise credibility of a sustainability report.

Park\&Brorson (2005) found that while some corporations have their voluntary assurance of sustainability report due to the benefits sited above, there are still some other companies which are not willing to perform such an assurance for one cause or another. Among these reasons, $31 \%$ of the companies could not afford audit fees, which is a more common situation among small companies; $31 \%$ of the companies doubts whether such voluntary assurance of sustainability report can rise the value of sustainability reports; $25 \%$ of the company consider it is the wrong timing for them to do voluntary assurance, they have more important works to do. The final $13 \%$ of the companies hold the opinion that only large enterprises have the necessary to do it. Voluntary assurance of sustainability report needn't to be carried out since they don't have any competitive pressure. From what have been discussed above, we can make it clear that audit fees influences the most of voluntary assurance of sustainability report. Thus, analysis of the relationship between sustainability report and audit fees is of great importance.

\section{Literature Review}

\subsection{Voluntary Assurance of Sustainability Report}

Voluntary assurance of sustainability report came into people's view two decades ago and become prevalent more 
recently.

Patrick Velte and Martin Stawinoga, in their article called Empirical research on corporate social responsibility assurance (CSRA): a literature review, put forward that decisions of voluntary assurance of sustainability report and the choice of assurance provider are related to firm characteristics, corporate government issues and country-specific variables after reviewing 53 empirical CSRA studies and analyze the consequences of CSRA. A conclusion also came up by them that voluntary assurance may enhance the credibility of sustainability report from the perspectives of investors. However, this conclusion missed out other groups of stakeholders, that may lead to its one sidedness. So after that, some scholars turn their attention to the role stakeholders play in sustainability report. Giacomo Manetti and Simone Toccafondi in their thesis The Role of Stakeholders in Sustainability Reporting Assurance mentioned that stakeholders are significantly consulted by assurance providers during the assurance services. Besides, stakeholders play an important role in all stages of the sustainability report assurance process. There are still some other scholars studies corporate social responsibility assurance from a new aspect. Lin Liao, Teng (Philip) Lin and Yuyu Zhang revealed the relation between corporate board and voluntary assurance of sustainability report in their article Corporate Board and Corporate Social Responsibility Assurance: Evidence from China. The authors investigated 2054 firm-years of Chinese listed companies with CSR reports from 2008 to 2012 and discovered that if a company have a larger board size, more female directors and separation of CEO and chairman positions in their company, they are more likely to engage in CSR assurance. On one hand, their conclusions are based on diversities factor which impact on corporate voluntary assurance of sustainability report and including quite amount of data and examples. On the other hand, the ultimateness only exists in the Chinese setting. It is less persuasive in some way. Another paper named Enhancing the Role and Effectiveness of Corporate Social Responsibility (CSR) Reports: The Missing Element of Content Verification and Integrity Assurance published by S. Prakash Sethi, Terrence F. Martell and Mert Demir focuses on measurement criteria of assurance of corporate social responsibility report. According to the paper, voluntary assurance lacks robust measures pertaining to the quality and accuracy of the reports' content. The paper also came out the conclusion that western European firms are more likely to attain assurance for their CSR reports and at a higher quality than those in East Asia and North America.

\subsection{Audit Fees}

Audit fees are another vital component related to voluntary assurance of sustainability report. Fair value and audit fees published by Igor Goncharov, Edward J. Riedl and Thorsten Sellhorn discloses that firms reporting property assets using fair value cost lower audit fees by using the European real estate industry as their primary setting. Prior study estimated the determinants of audit fees piecemeal until Rick Antle, Elizabeth Gordon, Ganapathi Narayanamoorthy and Ling Zhou released a paper called the joint determination of audit fees, non-audit fees, and abnormal accruals. By using the data of non-audit and audit fee from the UK for 1994-2000 and calculating a simultaneous set of equations. The paper shows that the higher audit fees cost, the more acceptances of abnormal accruals are. However, no evidence shows that fees for non-audit services increase abnormal accruals. Meanwhile, researchers show great interest in relation between audit technology and audit fees. The paper written by Hema Rao and K. F. Gheyana called An Empirical Evaluation of the Association Between Audit Technology and Audit Fees is the most representative one. It classified audit technology into three groups: structured, unstructured and intermediate. The result indicated that different audit technology influence the efficiency and greater efficiency means lower costs. To make it more clear, those with structured audit technology possess higher efficiency and have lower costs. In another paper, Audit Fee Determination and Governance Structure: Empirical Evidence from UK Insurance Companies took a disparate step in assessing the audit fees-- a company's governance quality. Several empirical examination were indicated, such as the effects of organisational form, class of business, and board composition. The paper finally gave a conclusion that less audit fees would be paid by those companies which possess strong internal governance and weak external governance. To sum up, both voluntary assurance of sustainability report and audit fees can be influenced by many factors and it takes rather complicated work to attain a full understanding of them.

\section{Development of Hypotheses}

From the current researches at home and abroad, some scholars highlight the relationship between sustainability report and financial performance while other turns their heads to establish connection between corporate social responsibility corporate risks. Nevertheless, relation between voluntary assurance of sustainability report and audit fees still lack enough researches. Chen et al.(2012), according to his research based on samples of KDL2000-2008 social responsibility credit rating, indicated that those who have better sustainability reports cost fewer audit fees. Whether good companies with better social responsibility reports would lower corporate risk, thus to lower auditor's audit 
risk or even have some impacts on the cost charged by auditors? Two key hypotheses were put forward, hypothesis 1 : Audit fees are decided by the working hours of auditors on assurance. Hypothesis 2: A better sustainability report cost fewer working time on assurance, thus, reduce the audit fees. In the very first point, we studied different corporation's assurance reports published in the same period (January, 2012), variable is the rating of the result of voluntary assurances, the result comes up that the same auditor charges less on high level of assurance and more on corporations with worse performance.

Hay et al. (2006) summarized literature of determinant on audit fees, which indicates audit fees are decided by the working hours of auditors on assurance. More specifically, audit fee is the sum of working hours times unit price. Unit price is decided by diverse factors such as auditors' acceptable audit risks.

With the in-depth study, research goes in a broader vision. Most companies are facing regulatory risk, legal risk and reputation risk. Once these risks go high, auditors' acceptable audit risks go low, as a result of which, they have to spend more hours on providing necessary assurance. Hence, auditors will require a more audit fees so that they can lower the risk to a more acceptable low level. A more creditable sustainability ability has a close connection among low external regulatory risks between companies and auditors, low legal risks and low reputation risks. These are also important marks to responsible management of a company. By doing so, corporations have reduced the level of auditors' misstatement risk and audit time. They would spend less time verifying the report, thus a great amount of time being saved leads to a lower cost of audit fees.

However, on the contrary, corporations' lack of social responsibility would add up times, that is to say, auditors have to pay more attention and time on verifying the report which is sent by the company. From this point of view, more expensive audit fees are charged is for sure. It is undeniable that companies' voluntary assurance of sustainability report implies that they take social responsibility initiatively. It is another way for the company take to show their stakeholders and auditors that they are confident for their sustainability report and the report is completely reliable. Voluntary assurance of sustainability report in some way also leaves a good impression on auditors' minds by telling them that the report is totally open and transparent. In psychology, it is called mental superiority and this can be a helping role. Finally, it is worth noting that lacking unified standard, the charge of audit fees varies from one to another, such disordered situation is still waiting to be solved. Luckily, both corporate voluntary assurance of sustainability report and audit markets are heading the right direction and right way, the whole industry are justifying itself into a healthy development model.

\section{Research Methods}

This research proposal has integrated research methods of normative study and empirical study.

Firstly, based on previous researches on voluntary assurance and sustainability report and audit fees home and abroad, the author selected and used a set of alternative data concerned to Australian listed companies' current situation of voluntary assurance of sustainability report, then we developed a general review on whether voluntary assurance of sustainability reports have any impact on audit fees charged by the auditors have been put forward. Research topic and contents are confirmed on this basis.

Secondly, we analyzed possible factors which might influence audit fees and explained how voluntary assurance of sustainability reports would impact on audit fees. This is a step to lay a theoretical foundation.

Thirdly, the author combined all the current developmental situations of voluntary assurance of sustainability report empirical studies and gave suggests on the development of voluntary assurance of sustainability reports.

These three steps above are normative study. In empirical study, the author focus on ten samples of sustainability report and voluntary assurance quote submitted by the same auditors. Using SPSS19.0 statistical software, the author designed a Logistic regression model to deepen and verify the hypothesis.

The independent variable of this research are different levels of corporation's assurance report, dependent variable is audit fees. Some relevant control variables are reports under the same period, same auditor and make sure such audit is fair and square and doesn't have prejudice.

Sources of information to be used to gather relevant data is from KDL2000-2008 social responsibility credit rating, the author sample 10 copies of typical companies' sustainability reports for the research. Corporate internal characteristic variable data is from CSMAR data base. Before the data were put into the model, descriptive statistics were executed. Whole sample descriptive statistics analysis and sub-example descriptive statistics analysis are both involved. The correlation of variable test need to be carried out for the purpose of testing the relationship between the variables, as well as testing whether there is any presence of multicollinearity. Moreover, in order to make the research result 
more reliable, this proposal adds up a test method called robustness test. For example, there happens to be no or slight statistical significance. It means this model is in good robustness and the result can be trusted. In this thesis, after doing the robustness test in the samples, just slightly change happen in the test, which means the model in the thesis is in good robustness. All these research methods and designs are providing a guarantee for the empirical study. Thus, make sure that this thesis is so rigorous that the result and the conclusion are both scientific, neutral and reliable as well.

\section{Conclusions}

For one thing, Sustainability reporting and assurance of sustainability reports have been used by organisations in an attempt to provide accountability to their stakeholders. For another, independent auditors as professional assurance providers of capital market have responsibility to lend credibility to financial statements and are more likely to be sensitive to any value-added behavior and information of their clients. Therefore, sustainability assurance can provide additional information for financial statement auditors to assess their exposed audit risk. Voluntary assurance of sustainability reports provided by listed companies does have some impact on audit fees charged by the auditors. Besides, it presents its relation in a negative correlation way. Enterprises should better and strengthen its internal management and normalize work targets and take social responsibility own its own initiative. Not only to carry out a better result of voluntary assurance of sustainability reports and lower the expenses, but to lead a more positive and healthy market environment. We can still figure out that the number of companies which release their sustainability reports or carry out voluntary assurance of sustainability reports is still too small, which is a concentrated expression of industries' loosely regulated. Every corporation should consciously join this effort and join hands to create a better industrial society.

\section{References}

Brazel, J.F., K.L. Jones, \& D.F. Prawitt. (2011). Improving fraud detection: Do auditors react to abnormal inconsistencies between financial and non-financial measures?. Brigham Young University, Working Paper. https://doi.org/10.2139/ssrn.1534778

Chen, Long, Bin Srinidhi, Albert Tsang, \& Wei Yu. (2012). Corporate social responsibility, audit fees, and audit opinions. George Mason University, Working Paper.

Dhaliwal, D.S., O.Z. Li, A. Tsang, \& G.Y. Yang. (2011). Voluntary nonfinancial disclosure and the cost of equity capital: the initiation of corporate social responsibility reporting. The Accounting Review, 86(1), 59-100. https://doi.org/10.2308/accr.00000005

Dhaliwal, D.S., S. Radhakrishnan, A. Tsang, \& G.Y. Yang. (2012). Nonfinancial disclosure and analyst forecast accuracy: international evidence on corporate social responsibility disclosure. The Accounting Review, 87(3), 723-759. https://doi.org/10.2308/accr-10218

Giacomo Manetti, \& Simone Toccafondi. (2012). The role of stakeholders in sustainability reporting assurance. Journal of Business Ethics, (107), 363-377. https://doi.org/10.1007/s10551-011-1044-1

Hema Rao, \& K. F. Gheyana. (2011). An empirical evaluation of the association between audit technology and audit fees. Journal of Business Ethics, 1(1), 87-88.

Igor Goncharov, Edward J Riedl, \& Thorsten, Sellhorn. (2014). Fair value and audit fees. Journal of Business Ethics, (19), 210-241. https://doi.org/10.1007/s11142-013-9248-5

Kim, Y., M. Park, \& B. Wier. (2012). Is earnings quality associated with corporate social responsibility?. The Accounting Review, 87(3), 761-796. https://doi.org/10.2308/accr-10209

Klaus Ruhnke, \& Alexander Gabriel. (2013). Determinants of voluntary assurance on sustainability reports: an empirical analysis. Journal of Business Ethics, (83), 1063-1091. https://doi.org/10.1007/s11573-013-0686-0

Skapinker, M. (2011). Do corporate citizenship reports matter?. Financial Times, August 10, 2011. 